Nat. Hazards Earth Syst. Sci., 17, 1267-1283, 2017

https://doi.org/10.5194/nhess-17-1267-2017

(C) Author(s) 2017. This work is distributed under

the Creative Commons Attribution 3.0 License.

\title{
Efficient pan-European river flood hazard modelling through a combination of statistical and physical models
}

\author{
Dominik Paprotny, Oswaldo Morales-Nápoles, and Sebastiaan N. Jonkman \\ Department of Hydraulic Engineering, Faculty of Civil Engineering and Geosciences, Delft University of Technology, \\ Stevinweg 1, 2628 CN Delft, the Netherlands \\ Correspondence to: Dominik Paprotny (d.paprotny@tudelft.nl)
}

Received: 3 January 2017 - Discussion started: 5 January 2017

Revised: 10 June 2017 - Accepted: 23 June 2017 - Published: 21 July 2017

\begin{abstract}
Flood hazard is currently being researched on continental and global scales, using models of increasing complexity. In this paper we investigate a different, simplified approach, which combines statistical and physical models in place of conventional rainfall-run-off models to carry out flood mapping for Europe. A Bayesian-network-based model built in a previous study is employed to generate returnperiod flow rates in European rivers with a catchment area larger than $100 \mathrm{~km}^{2}$. The simulations are performed using a one-dimensional steady-state hydraulic model and the results are post-processed using Geographical Information System (GIS) software in order to derive flood zones. This approach is validated by comparison with Joint Research Centre's (JRC) pan-European map and five local flood studies from different countries. Overall, the two approaches show a similar performance in recreating flood zones of local maps. The simplified approach achieved a similar level of accuracy, while substantially reducing the computational time. The paper also presents the aggregated results on the flood hazard in Europe, including future projections. We find relatively small changes in flood hazard, i.e. an increase of flood zones area by $2-4 \%$ by the end of the century compared to the historical scenario. However, when current flood protection standards are taken into account, the flood-prone area increases substantially in the future (28-38\% for a 100 -year return period). This is because in many parts of Europe river discharge with the same return period is projected to increase in the future, thus making the protection standards insufficient.
\end{abstract}

\section{Introduction}

River floods are one of the most costly natural hazards in Europe. To identify the location and extent of flood risk, flood hazards have been mapped at the local and national scale. The maps provide high-resolution information for flood risk management; however they seldom include projected flooding under the influence of climate and socio-economic change. The EU Floods Directive requires revisions of flood maps every 6 years (European Union 2007). Yet, costs of detailed studies are high. For example, in England (2005-2013) the cost amounted to GBP 7 million (approx. EUR 10 million), not including the necessary surveys and data collection, which amounted to more than GBP 20 million (Environment Agency, 2016). The scope and extent of the studies vary across Europe, as does the level of dissemination, and few countries make the geospatial data underlying the flood maps easily available. Due to methodological differences, the comparability of the maps is limited and, consequently, the possibility of aggregating them and drawing Europe-wide conclusions is also hampered. Outside Europe, local flood maps are often not present at all.

To produce spatially consistent maps over large areas, several studies on European and global river flood hazard studies have been commissioned. In Europe a series of studies was recently made (Rojas et al., 2013; Alfieri et al., 2014, 2015a, b) using the Lisflood model (van der Knijff et al., 2010) to derive $100 \mathrm{~m}$ resolution maps for the continent. The same model has also been used in the European Flood Awareness System, or EFAS (Thielen et al., 2009), as well as its global extension, Global Flood Awareness System GloFAS (Dottori et al., 2016). On a global scale, recent river floods studies include GLOFRIS (Winsemius et al., 2013; Ward et al., 
2013), SSBN (Sampson et al., 2015) and analyses based on CaMa-Flood model (Pappenberger et al., 2012; Hirabayashi et al., 2013). The resolution of the resulting maps ranges from 3 to 30 inches, or approximately $90-900 \mathrm{~m}$ on the equator. Methodologies employed in the studies vary, but most start with coarsely gridded simulation of river flows based on meteorological and land surface data. Flood volumes calculated at $0.25-0.5^{\circ}$ resolution are typically downscaled and redistributed over finer grid cells to generate flood extents. In studies based on Lisflood model, a two-dimensional (2-D) hydrodynamic simulation was performed. However, validation of the models' accuracy has been limited over Europe. Only Alfieri et al. (2014), Winsemius et al. (2015) and Sampson et al. (2015) directly compare their estimated flood zones with local high-resolution studies. The practical use of the maps is also limited by rather small availability of the underlying data, which are mostly available as online visualizations or through direct contact with the authors. Additionally, the common assumption of the global maps is that there are no flood defences in place, thus constituting a worst-case scenario (Jonkman, 2013, Ward et al., 2015). On the other hand, an advantage of these models is that most of them do - or can - incorporate climate change and socio-economic developments needed to analyse changes in flood frequency over time.

However, calculating flood hazard for the whole continent or the globe is computationally demanding. Alfieri et al. (2014) mentions using a 60-processor cluster to perform a 2-D simulation of flood zones at $100 \mathrm{~m}$ resolution for one scenario only. Sampson et al. (2015) indicated that a similar calculation (3 inch grid, 2-D model) would take 3 months on a single processor core for an average $10^{\circ} \times 10^{\circ}$ grid box, which is roughly the geographical extent of metropolitan France. Using a 200-core cluster, the time is reduced to less than a day. Still, the question remains as to whether using complex models is necessary given the quality and resolution of the input data. Bates and De Roo (2000) compared output from three different model types with extents of an actual flood for a case study in the United Kingdom. They found that at $100 \mathrm{~m}$ resolution a 2-D dynamic model performed almost identically to a one-dimensional (1-D) steady state and improved estimates only slightly when compared to floodplains generated by extrapolating water levels from observations over the digital elevation model (known as a planar approach). In another case study in Germany, Apel et al. (2009) found only a small influence of model choice (water level interpolation, 1-D/2-D model, 2-D model) on the results of a flood risk analysis. Sampson et al. (2015) replaced hydrological modelling of river discharges with a statistical method, known as the regional frequency analysis (RFA). Applying the same hydraulic model as in Alfieri et al. (2014) to calculate flood extents, the researchers achieved a better fit to high-resolution flood maps of Thames and Severn river basins than the earlier study. A similar comparison for the two areas modelled using four global flood models was presented by Dottori et al. (2016). The results are not conclusive as to which modelling approach gives the best results.

In light of the above, it is not surprising that simpler approaches are still used for flood research. For the CFFlood data set (Mokrech et al., 2015), for instance, river flood extents were derived by using the planar approach based on water levels computed in Lisflood simulations from Feyen et al. (2012), albeit no validation was presented for either study. As mentioned before, Sampson et al. (2015) utilized a regional frequency analysis of river discharges that was presented by Smith et al. (2015). This study found that river discharges can be estimated by clustering gauge stations based on climate type, catchment area and annual rainfall. At any location, the discharge could be modelled through similarity of catchment parameters to those clusters. Paprotny and Morales Nápoles $(2015,2017)$ employed Bayesian networks to estimate extreme river discharges in Europe using seven geographical characteristics of catchments. The results have shown that similar accuracy to pan-European studies using hydrologic models could be achieved. Finally, for the lack of a better solution, flood defences have been omitted altogether in almost all studies. Occasionally, an assumption that more valuable areas are better protected was used to compile databases of flood protection standards (Mokrech et al., 2015; Scussolini et al., 2016).

The ultimate aim of the research presented in this paper was to construct flood hazard maps for Europe under present and future climates. This paper builds on the results of Paprotny and Morales Nápoles (2017). In the aforementioned paper, the authors show how extreme river discharges can be derived for the whole continent using only a statistical model. This paper extends the previous research by calculating river flood extents over the same area. A relatively simple combination of one-dimensional hydraulic simulation of water levels and GIS-based planar approach is utilized to draw flood zones herein. Emphasis is placed on analysing the accuracy of the results in terms of match with local high-resolution flood maps. This is put in context of the performance of more advanced models in the same areas. Additionally, the aggregate results of the analysis are presented to show flooded areas at various return periods, the expected changes in the level of hazard due to climate change and the influence of flood defence standards on the modelling outcomes

It should be noted that the work presented here was a part of a larger effort to create pan-European meteorological and hydrological hazard maps within the "Risk analysis of infrastructure networks in response to extreme weather" (RAIN) project. As a consequence, several design choices, such as the extent of the domain, source of input data or representation of the results, were made in order to synchronize the various hazard maps produced within the project (Groenemeijer et al., 2016). 


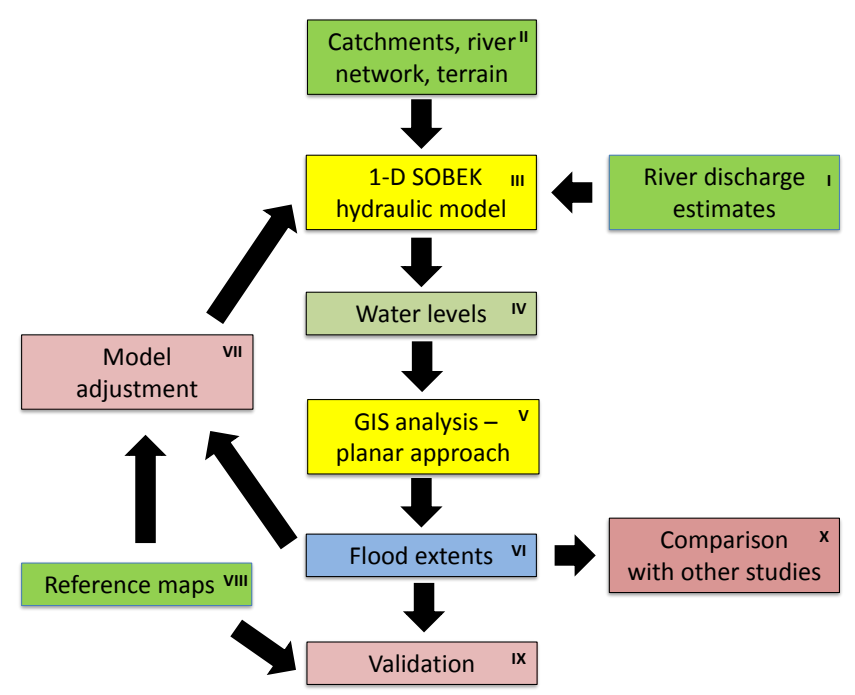

Figure 1. Schematic workflow of flood extent calculation. Roman numerals refer to the text.

\section{Materials and methods}

\subsection{Domain and overview of the methodology}

The analysis presented here was performed over a domain covering most of the European continent, the same as used by Paprotny and Morales Nápoles (2017). This domain excludes most of Russia, the Ukraine and Belarus, as well as some outlying island territories, but adds Cyprus, as it is a member of the European Union. In this area there are around 2 million $\mathrm{km}$ of rivers in more than 830000 catchments, according to the CCM River and Catchment Database v2.1, or CCM2 (Vogt et al., 2007; de Jager and Vogt, 2010). Within this domain, the smallest rivers are affected by flash floods and flooding cannot be represented using daily discharge extremes, as those phenomena last only a few hours or less. Therefore, a threshold of $100 \mathrm{~km}^{2}$ upstream area was chosen, which reduces the domain to 155664 river sections (19\% of the total), while retaining $26 \%$ of river length $(498420 \mathrm{~km})$. That is still more than double the $188300 \mathrm{~km}$ of rivers analysed in Alfieri et al. (2014). Global studies mostly used higher thresholds: $5000 \mathrm{~km}^{2}$ in Dottori et al. (2016), which

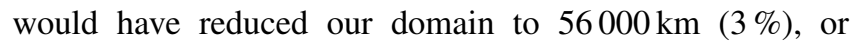
Strahler number of at least 6 in Winsemius et al. (2013), which would have had almost the same effect. The scope of the paper covers river floods; therefore influence of tides and storm surges is not included. Also, flash floods in very small catchments (below $100 \mathrm{~km}^{2}$ ), which occur over a short period of time, are not covered here.

In this domain, flood extents were calculated using the procedure presented in Fig. 1. First, river discharges estimates from the Bayesian-network-based model (I) are collected, as described in Sect. 2.2. Together with data on the river network and terrain (II), they serve as input data for a one- dimensional simulation of water levels using the SOBEK model (III). After the water levels (IV) have been calculated as per Sect. 2.3, they are transferred to GIS software (V). Flood zones (VI) are then delimited utilizing the planar approach (Sect. 2.4). The model in SOBEK is then adjusted (VII) based on the comparison with a set of reference maps (VIII), both local high-resolution studies and the Joint Research Centre's (JRC) map (Sect. 2.5). If necessary, this step could indicate new runs of the SOBEK model that adjust the model's roughness coefficient. Afterwards, the resulting flood extents are validated (IX) with additional reference maps and contrasted with the outcomes of other studies $(\mathrm{X})$, which are presented in Sect. 3.1. Finally, flood extents are calculated both for the reference period (1971-2000) and climate change scenarios.

\subsection{River discharge scenarios}

In the approach chosen for this study, only the peak discharge value is used in the hydraulic model, rather than flood volumes or time series of discharges. This is because the steady-state simulation calculates the equilibrium water level, there time factor is excluded (see Sect. 2.3). Estimates of annual maxima of river discharges were provided by the Bayesian-network-based (BN) model for three time periods 1971-2000, 2021-2050 and 2071-2100. The BN model was extensively described and validated in Paprotny and Morales Nápoles (2017) and the reader is referred to this paper for details.

Briefly, the BN model is a statistical method that constructs joint distributions over different random variables (different geographical properties of European catchments in our case) in a parsimonious way (Pearl, 1988). In the model, seven random variables are used to conditionalize annual maxima of river discharges in a non-parametric, continuous BN. Those variables are represented as nodes of the BN, while the dependencies between them are represented as arcs joining different nodes. An arc represents the (conditional) correlation between two variables, and has a defined direction. The arcs have to connect the nodes in such a manner that the resulting graph is acyclic; i.e. if we chose any node and strictly follow the direction of all arcs in a path, we will not end up at the same node. It is assumed that the dependencies between variables can be modelled using a normal (Gaussian) copula. The variables used in the BN are catchment area, catchment steepness, annual maximum of daily precipitation and snowmelt, extreme run-off coefficient and three types of land use expressed as \% of total catchment area (lakes, marshes and built-up areas).

Between the aforementioned time periods all variables remain constant within every catchment, except annual maximum of daily amount of precipitation and snowmelt and the run-off coefficient (annual maximum of total run-off divided by the previously mentioned variable). This information is collected from climate models. It allows the method 


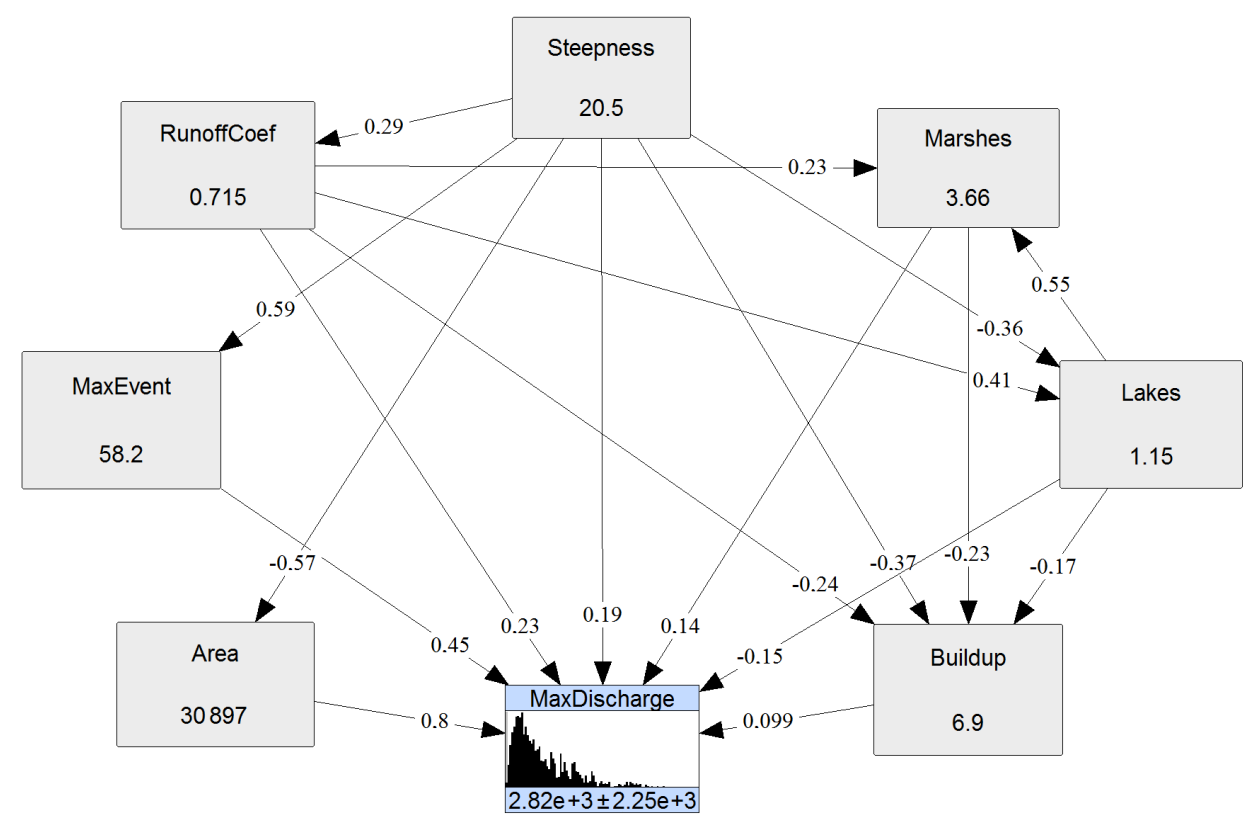

Figure 2. Conditionalized Bayesian network for annual maximum discharge in the river Rhine at Basel station in Switzerland in the year 2005. The uncertainty distribution of discharge is shown, with a mean of $2820 \mathrm{~m}^{3} \mathrm{~s}^{-1}$ (MaxDischarge).

to provide discharge estimates and a full conditional distribution for any climate scenario and time period based on output from climate models (Fig. 2). Here, results from one of the high-resolution $\left(0.11^{\circ}\right)$ regional models operated within EURO-CORDEX framework was used, produced by the Climate Limited-area Modelling Community utilizing the EC-Earth general circulation model (run by ICHEC) with COSMO_4.8_clm17 regional climate model (Rockel et al., 2008), realization r12i1p1 (see Paprotny and Morales Nápoles, 2017 for details on data sets used in the European BN model). The first one is the historical reference period, used to calibrate and validate the method's performance. The other two represent climate change scenarios, or future projections. Each of those future scenarios consists of two variants, namely Representative Concentration Pathways or RCPs. RCP 4.5 and RCP 8.5 indicate changes in emissions that would cause an increase in radiative forcing by 4.5 or $8.5 \mathrm{~W} \mathrm{~m}^{-2}$ by 2100 (Moss et al., 2010). Finally, extreme value analysis with Gumbel distribution was applied to obtain discharges with different return periods.

Yet, some additional work was necessary to use the extreme discharge estimates in the hydrodynamic simulation. All large-scale flood assessments face the problem of missing channel geometry data. Most of the time, the problem is solved by using the assumption that the satellite-derived digital elevation model represents the surface water at normal conditions. Thus, in this study, only the flow above the surface under normal conditions is considered. This baseline flow is therefore subtracted from the peak discharge estimates. It could be the mean annual discharge (Alfieri et al.,
2014; Dottori et al., 2016) or the bankfull discharge, which is assumed to be equal to a 2-year return period (Ward et al., 2013; Sampson et al., 2015). Here we used the former approach, as it gave slightly better results than the other when comparing the flood extents with the reference maps. To estimate mean discharge, the $\mathrm{BN}$ model was modified by replacing the two variables representing the extreme meteorological events, namely annual maximum of daily precipitation combined with snowmelt and extreme run-off coefficient (annual maximum of total run-off divided by maximum of precipitation and snowmelt), with their equivalents for average climatology. Therefore, mean annual precipitation and average run-off coefficient (mean annual total runoff divided by mean annual precipitation) are considered. The BN was quantified for 1841 catchments using the same sources of data as before, and contrasted with the observations from gauge stations (Fig. 3). The coefficient of determination $\left(R^{2}\right)$ is 0.93 , which is the same value reported in Rojas et al. (2011) for a hydrological model of Europe without biascorrection of climate data. For specific river discharge, i.e. run-off divided by the respective catchment areas, the $R^{2}$ is 0.60 . The Nash-Sutcliffe efficiency $\left(I_{\mathrm{NSE}}\right)$, which measures the fit to a $1: 1$ line, equals 0.85 . This is better than -0.39 reported in Rojas et al. (2011), but only when the river discharge calculation was performed using climate data not corrected for bias. With bias-corrected climate data, the model by Rojas et al. (2011) had almost perfect fit with the observations $\left(I_{\mathrm{NSE}}=0.99\right)$. 
(a) Mean annual discharge $\left(Q_{m}\right)$

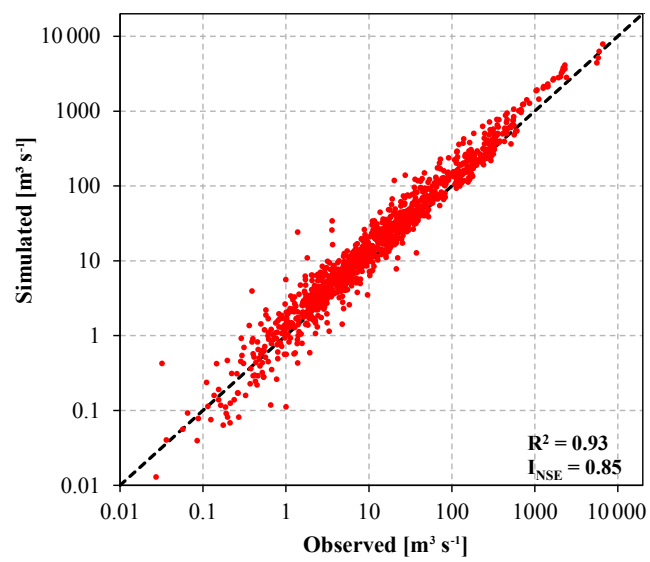

(b) Specific mean annual discharge $\left(Q_{m}\right)$

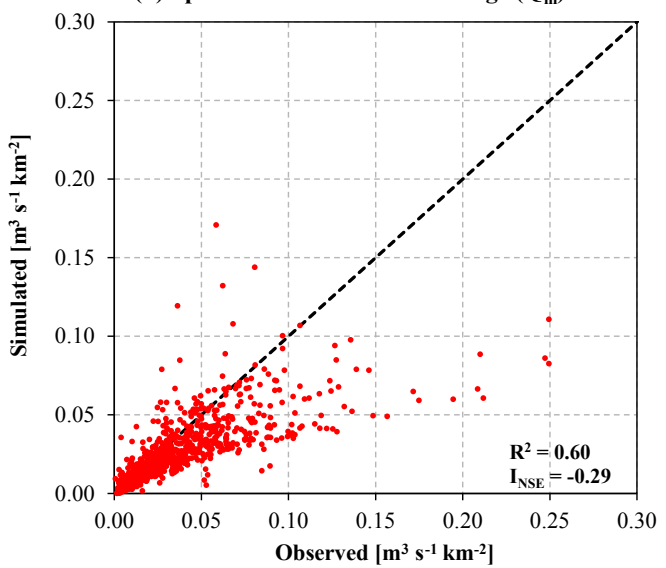

Figure 3. Comparison of simulated and observed mean annual river discharges using a Bayesian network: (a) actual values, (b) specific discharge (run-off divided by the respective catchment area).

\subsection{River water level modelling}

Calculation of water levels was performed using the SOBEK v2.13 hydrodynamic model (Deltares, 2016). As noted in the introduction, the one-dimensional (1-D) module was chosen, as it is significantly less computationally demanding than a two-dimensional (2-D) model. One-dimensional flow is described by de Saint-Venant's continuity and momentum equations. Also, a steady-state calculation was performed: the model iteratively performs the simulation until an equilibrium state of water level for a given discharge amount is found. This means that discharge is assumed to be nonvariable in time, which reduces the computational effort compared to an unsteady calculation in which water levels are calculated for each defined time step. The hydraulic simulation was prepared utilizing six inputs: river network geometry, river cross sections, calculation points, upstream and downstream boundaries, lateral discharge and model parameters.

The geometry of the river network was obtained from the linear representation of the rivers in the CCM2 data set. As noted in Sect. 2.1, river sections with catchment areas of at least $100 \mathrm{~km}^{2}$ were selected. The network was divided into seven subsimulations based on the regional split of the original CCM2 data set (Fig. 4). The resolution of the geometry is about $100 \mathrm{~m}$. Cross sections of the rivers were derived from the EU-DEM elevation model (DHI-GRAS, 2014) at $100 \mathrm{~m}$ resolution. They vary in length depending on the characteristics of the topography (elevation differences) so that the maximum extent of the floodplain is captured. The density of the cross section along the rivers also varies. CCM2 data set splits rivers into segment whenever two rivers merge; thus, the number of cross sections per segment depends on its length. On average, the cross sections are $2.1 \mathrm{~km}$ apart. Due to the low resolution of the DEM two assumptions had to be made: first, that the DEM represents the average water level in the river, as discussed in the previous section, and second, that no flood defences or other discharge-control structures are present (unless dykes are large enough to be captured by the DEM). The latter assumption is featured in all continental and global studies and sometimes even in national studies, such as the flood assessment for England. The aspect of flood protection was dealt with outside the hydraulic computation itself (see Sect. 2.4).

Another input element, calculation points, are locations along the digitized river network where the 1-D model computes the water levels. A 1-D model represents the rivers and channels as a linear object, therefore allowing movements of water along a single dimension. The dimensions of the river bed and floodplain are defined on the cross sections. The method utilizes de Saint-Venant's equations to calculate discharges in a longitudinal profile at calculation points. As another computational-time-conserving simplification, the lumped conveyance approach was used rather than vertically segmented approach. This means that it is assumed that velocity is uniform along the profile, as opposed to allowing different velocities in each defined vertical segment. Similarly to cross sections, calculation points vary in density and were defined in such a manner that they are located between the cross sections. Their total number is slightly higher so that the average distance between them is $2 \mathrm{~km}$.

Computation of river flows in the network is limited by boundaries. Because a threshold of $100 \mathrm{~km}^{2}$ catchment area is used, almost all upstream boundaries are located somewhere along the rivers and discharge values were drawn from the $\mathrm{BN}$ estimates for that particular location. In rare cases for which the source river section already has a catchment bigger than the threshold, the value of discharge was taken from the BN estimate made for that catchment. As noted earlier, average discharge was subtracted from the extreme discharge value for the purpose of the calculation. Meanwhile, the downstream boundaries are the locations where the rivers 
connect to the sea. The only exceptions are two rivers draining to lake Prespa in the southern Balkans. The boundary was defined as zero water level, representing the mean sea level unless the DEM indicated a value lower than zero. This could be due to a river moving through a depression, bias in the DEM or the difference between the mean sea level and modelled geoid underpinning the DEM.

Between the upstream and downstream boundaries the discharge increases as more catchment area contributes to the river flow; therefore more discharge had to be added along the river network. Lateral discharge nodes are used here so that water can enter the model at locations that are different to the boundaries. This is also necessary to properly represent the discharge scenarios in the network. At an intersection of two rivers, the water flow in both rivers is summed and continues downstream. However, extreme discharges, for example with a 100-year return period, do not necessarily occur at the same moment in adjacent rivers. Hence, the 100-year discharge in the river segment below the intersection will be typically lower than the sum of the two contributing rivers. Using the lateral discharge option, the surplus water is withdrawn from the model, preserving a proper representation of flood scenarios.

The final aspect to be considered is the model parameters. The most important parameter is the roughness coefficient which was chosen through a relatively simple process. Other large-scale studies did not perform any calibration due to the lack of comparison material with sufficient spatial coverage. Here, we compare our flood map for the historical scenario, prepared as described in Sect. 2.4, with the JRC map (Alfieri et al., 2014). Even though the JRC map was uncalibrated and by necessity only selectively validated, it used more advanced modelling steps which, most likely, resulted in higher accuracy. The roughness coefficient was assumed to be a constant value throughout each of the seven subsimulations. In five of them, the best results were achieved with a Manning's coefficient in the range of $0.13-0.15 \mathrm{~s} \mathrm{~m}^{-1 / 3}$. Two remaining regions (both in northern Europe) had lower values, likely due to large lake cover. The methodology of map comparison is explained in Sect. 2.5.

\subsection{Flood extent calculation}

Water levels obtained from the model were post-processed first by linearly interpolating them along the rivers to increase the density of estimates. For each point, located on average $250 \mathrm{~m}$ away from the next point, the nearest neighbourhood was defined with Thiessen polygons. For each polygon, a constant water level was assumed, therefore extrapolating the water levels over all terrain. Coastal segments were included in the nearest-neighbour calculation in order to avoid a situation where the water levels in a river are extrapolated along the coastline. Elevation from the DEM was then subtracted, per grid cell, from those water levels. From the whole area lying below water levels of the river, only those zones that

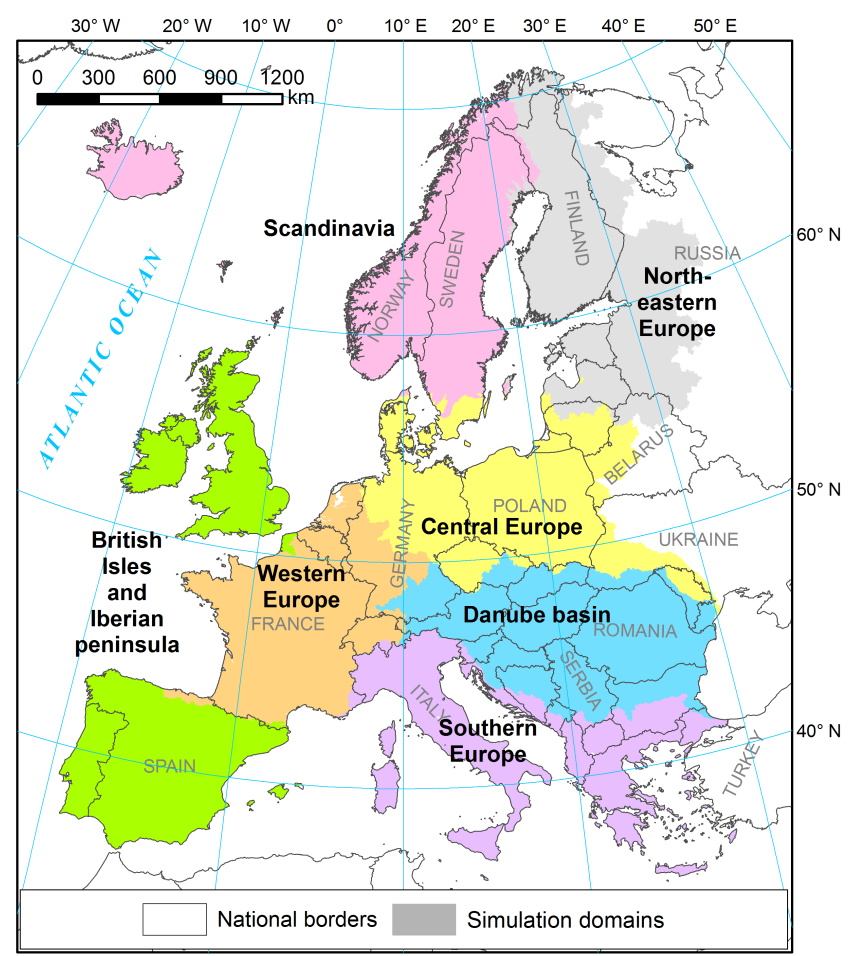

Figure 4. Division of the model into seven subsimulations, overlaid with political boundaries.

were hydrologically connected with the rivers were included. In other words, high terrain completely surrounding a lowlying area prevents it from being inundated.

Similarly to the water level modelling approach, there are two main drawbacks. First is the lack of flood volume control, which has a large influence on the actual flood extent during an extreme event (Apel et al., 2009). Second, it assumes that anything elevated above the water levels prevents inundation, which neglects the possibility of flood defence failure. However, flood defences can hardly be represented within the resolution of the model. Yet, due to high significance of this aspect, two sets of maps were produced. The first one directly uses the results of the analysis and can therefore be dubbed the "without flood protection" scenario. The second group corresponds to the maps "with flood protection". To obtain them, flood defences were assumed to have the same protection standard as calculated by Scussolini et al. (2016) in the FLOPROS database. This data set provides protection standards defined as return periods of river floods. As a result, it was assumed that the return periods in those protection standards were equal to return periods of discharges calculated with the Bayesian-network-based model ( $Q_{\mathrm{p}}$ in Fig. 5). If extreme discharge is higher than the protection standard $\left(Q_{\mathrm{e}}>Q_{\mathrm{p}}\right)$, the terrain floods.

Additionally, using the results of Paprotny and Morales Nápoles (2017), it was possible to calculate how the return period of discharge would change in the future for each 


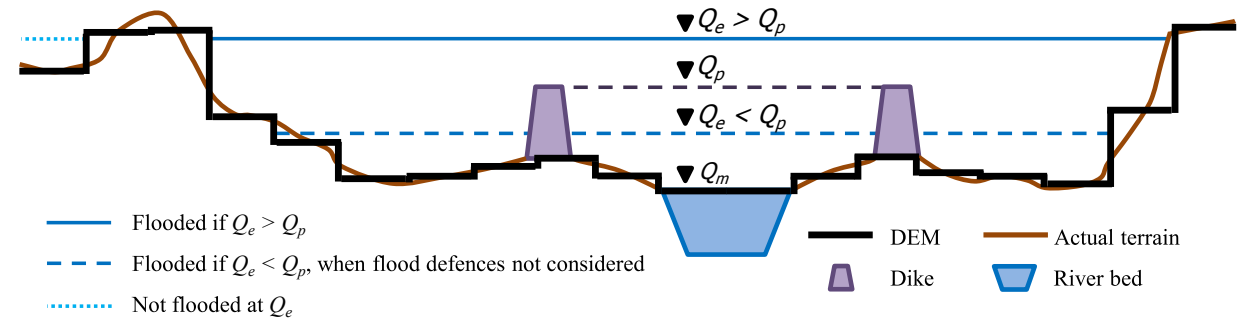

Figure 5. Cross section through a river valley and main model assumptions. The DEM is considered to represent terrain without flood defences and the river water surface at mean discharge $\left(Q_{\mathrm{m}}\right)$. Terrain represented in the DEM floods at extreme discharge $Q_{\mathrm{e}}$ if either no flood defences are considered or when $Q_{\mathrm{e}}>Q_{\mathrm{p}}$, i.e. when extreme discharge is higher than the protection standards.

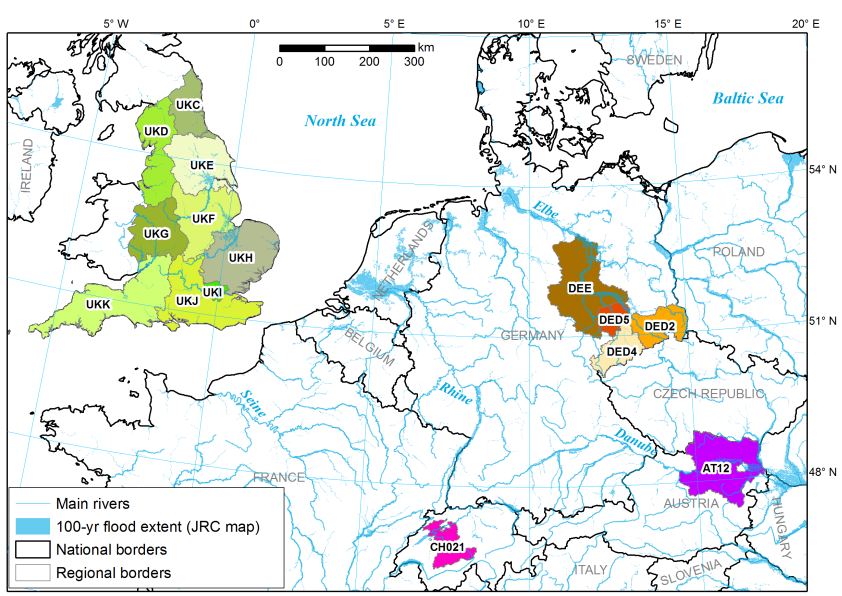

Figure 6. Location of the local reference maps with corresponding NUTS codes (see Table 2), with the JRC's flood map (Alfieri et al., 2014) presented in the background.

climate scenario and river segment. This would indicates whether the current protection standard will remain sufficient under climate change. For instance, consider a dyke that protects against a 200-year flood $\left(Q_{\mathrm{p}}\right)$ according to FLOPROS. It is therefore sufficient to withstand 100-year river discharge under the historical (1971-2000) scenario. If the extreme river discharges increase due to climate change, the future 100-year event will correspond to river discharge that currently has a return period of more than 100 years, say 250 years. In that case, discharges with a 250 -year return period are higher than the 200-year protection standard $\left(Q_{\mathrm{e}}>Q_{\mathrm{p}}\right)$. Therefore, the area that is currently protected against a 100 -year event will be at risk of inundation under climate change.

\subsection{Reference flood maps}

The results of this study (TUD map) were compared with six reference maps: one pan-European map and five regional flood maps. Below we briefly summarize the main characteristics of those studies (Table 1). The extent of local maps is presented in Fig. 6.
The pan-European map is available from the Joint Research Centre (2014) and it is documented in Alfieri et al. (2014). The map was created by firstly running a rainfallrun-off simulation of river discharges based on interpolated climatological data for 1990-2010. Based on those results, 100-year discharges together with a flood wave hydrograph was estimated; this is the only scenario considered. Twodimensional hydrodynamic model Lisflood was used to derive flood zones. The study utilized an SRTM terrain model and therefore does not include flood defences. The rainfallrun-off model was calibrated against river gauge observations, but the flood extent modelling was not calibrated. The resulting map covers $188300 \mathrm{~km}$ of rivers (with a $500 \mathrm{~km}^{2}$ catchment area threshold) in a domain that is slightly smaller than the one used here; it omits Cyprus, Iceland and parts of river basins that are located inside the former Soviet Union territory, except basins of the Danube, Vistula and Nemunas. The map's resolution is $100 \mathrm{~m}$ and it exactly matches the grid used in the TUD map.

The largest of the regional maps is the Environment Agency's (2016) Risk of Flooding from Rivers and Sea map of England. This data set was produced during 20052013 utilizing local-scale modelling and takes into consideration the height, type and condition of the flood defences. The resulting maps were validated locally using experts' assessments. They are continuously updated; the version from April 2015 was used here. The data set's resolution is $50 \mathrm{~m}$ and for the use in this study the flood zones inundated directly from the sea were removed. The map was prepared in four thresholds defined by the flood extents corresponding to return periods: below 30, 30-100, 100-1000, above 1000 years. The largest flood zones are observed in the basins of rivers Great Ouse and Trent. Much lower hazard is indicated along the biggest rivers, Severn and Thames.

Two maps from Germany were collected, covering the federal states (Bundesländer) of Saxony (Sächsisches Landesamt für Umwelt, Landwirtschaft und Geologie, 2016) and Saxony-Anhalt (Landesbetrieb für Hochwasserschutz und Wasserwirtschaft Sachsen-Anhalt, 2016). Both were prepared by the states' administration in 2015 , but they followed certain national regulations. In both cases, the maps take into 
Table 1. Comparison of main modelling techniques and assumptions in the maps considered in this study.

\begin{tabular}{|c|c|c|c|}
\hline Aspect & Pan-European map (TUD) & Pan-European map (JRC) & Local reference maps \\
\hline River discharge model & $\begin{array}{l}\text { Bayesian network for extreme } \\
\text { river discharges (statistical } \\
\text { model for Europe) }\end{array}$ & $\begin{array}{l}\text { Rainfall-run-off model (Lis- } \\
\text { flood) }\end{array}$ & $\begin{array}{l}\text { Mostly river gauge observa- } \\
\text { tions }\end{array}$ \\
\hline Flood scenarios & $\begin{array}{l}\text { Peak discharge with a return pe- } \\
\text { riod assumed to follow Gumbel } \\
\text { distribution }\end{array}$ & $\begin{array}{l}\text { Flood hydrograph created with } \\
\text { a empirical formula with a re- } \\
\text { turn period assumed to follow } \\
\text { Gumbel distribution }\end{array}$ & $\begin{array}{l}\text { Discharge with a return pe- } \\
\text { riod; methodology varies be- } \\
\text { tween studies }\end{array}$ \\
\hline Water level modelling & $\begin{array}{l}\text { 1-D hydrodynamic model } \\
\text { (steady-state), no channel } \\
\text { geometry }\end{array}$ & $\begin{array}{l}\text { 2-D hydrodynamic model } \\
\text { (Lisflood-ACC), no channel } \\
\text { geometry }\end{array}$ & $\begin{array}{l}\text { 1-D, hybrid 1-D/2-D or 2-D hy- } \\
\text { drodynamic model, depending } \\
\text { on importance of a location and } \\
\text { study }\end{array}$ \\
\hline Calibration of river flow & $\begin{array}{l}\text { Based on comparison with JRC } \\
\text { map }\end{array}$ & None & $\begin{array}{l}\text { Usually calibrated using river } \\
\text { gauge observations }\end{array}$ \\
\hline Flood zone modelling & Planar approach in GIS & $\begin{array}{l}\text { 2-D hydrodynamic model } \\
\text { (Lisflood-ACC) }\end{array}$ & $\begin{array}{l}\text { 1-D, hybrid 1-D/2-D or 2-D hy- } \\
\text { drodynamic model, depending } \\
\text { on importance of a location and } \\
\text { study; occasionally GIS only } \\
\text { for areas of low importance }\end{array}$ \\
\hline $\begin{array}{l}\text { Validation of results } \\
\text { (flood extents) }\end{array}$ & With local reference maps & With local reference maps & Local knowledge and expertise \\
\hline Output resolution & $100 \mathrm{~m}$ & $100 \mathrm{~m}$ & $5-50 \mathrm{~m}$ \\
\hline Flood defences & $\begin{array}{l}\text { Included in post-processing of } \\
\text { the maps (estimated protection } \\
\text { standard) }\end{array}$ & Not included & $\begin{array}{l}\text { Included in the river flow/flood } \\
\text { zone modelling (dimensions, } \\
\text { type of defences, sometimes } \\
\text { their condition as well) }\end{array}$ \\
\hline $\begin{array}{l}\text { Simulation run time on a } \\
\text { desktop computer }\end{array}$ & 1 day per scenario & $\begin{array}{l}\text { Computer cluster used (not fea- } \\
\text { sible on a desktop computer) }\end{array}$ & $\begin{array}{l}\text { From a few seconds (1-D) to a } \\
\text { few days (2-D) }\end{array}$ \\
\hline
\end{tabular}

account the effect of flood defences and include 1-in-100year flood scenario. The maps are provided in vector format, but their accuracy ought to be similar to a $1: 25000$ map $(>25 \mathrm{~m})$. Both regions are almost completely within the Elbe's river basin and most of the flood zone is along this river. Another map was obtained for the state of Lower Austria (Amt der NÖ Landesregierung, 2016). It is provided in vector format for three scenarios: 30-, 100- and 300-year floods. The impact of flood defence structures is included in this map which was produced in 2012 using 2-D modelling. Most of the flood zone is connected with the Danube or its tributary, Morava river.

The final map is from the Swiss canton of Bern (Kanton Bern, 2016) which is located within the basin of Aare river, a tributary of the Rhine. It was prepared in $1: 5000$ scale from 1997 and 2011 multi-hazard assessments and takes into account the effect of flood defences. However, this is a flood risk map and, due to its graphical representation, only the 1-in-300-year flood scenario could be extracted from it. Additionally, this map only includes flood zones that incorpo- rate populated areas. A map for the uninhabited zones exists in lower resolution (1:25000), albeit it does not include information on return periods. Therefore, the risk map for the 300 years scenario was compared with our 1-in-300-year flood overlay, while the combination of all flood zones indicated in the two Swiss maps was compared with the 1-in1000 year map.

The local maps required some modifications for the purpose of comparing them with the pan-European map. They were resampled to $100 \mathrm{~m}$ resolution and flood zones were removed if related to rivers with catchment areas below $100 \mathrm{~km}^{2}$ (for comparison with the TUD map) and $500 \mathrm{~km}^{2}$ (for comparison with the JRC map). The latter point was problematic in the sense that flood zones could be connected to multiple rivers, some of which could be below or above the $100 / 500 \mathrm{~km}^{2}$ threshold; flooding from a larger river can also spread over smaller tributaries. Therefore, as in Alfieri et al. (2014), a $1.5 \mathrm{~km}$ buffer around the rivers bigger than the threshold was used for selecting flood zones from the full map. 
The pan-European map was evaluated with two measures, the same as used by Bates and De Roo (2000) and several later studies. Test for correctness (or hit rate) indicates what percentage of the reference map is recreated in the panEuropean map (Eq. 1). As this test does not penalize overestimation, the test for fit (or critical success index) is applied (Eq. 2). They are calculated as follows:

$I_{\text {cor }}=\frac{A_{\mathrm{EM}} \cap A_{\mathrm{RM}}}{A_{\mathrm{RM}}} \times 100$
$I_{\mathrm{fit}}=\frac{A_{\mathrm{EM}} \cap A_{\mathrm{RM}}}{A_{\mathrm{EM}} \cup A_{\mathrm{RM}}} \times 100$,

where $A_{\mathrm{EM}}$ is the area indicated as flooded in the TUD panEuropean map and $A_{\mathrm{RM}}$ is the area indicated as flooded in the reference map. The TUD map was compared using the $100 \mathrm{~km}^{2}$ threshold with the five local maps for all available scenarios and with the JRC map using the $500 \mathrm{~km}^{2}$ threshold. Both pan-European maps were then compared with five local maps for the 100-year scenario (i.e. without the Swiss map) with a $500 \mathrm{~km}^{2}$ threshold. The results for England and Saxony were split into smaller regions for a more detailed overview using Eurostat's (2015) nomenclature of territorial units for statistics (NUTS). England is subdivided into nine statistical regions, while Saxony has three Direktionsbezirke, or districts. The comparison between the TUD and JRC map is presented for seven regions of Europe, the same as the seven subsimulations, as in Fig. 4.

\section{Results}

\subsection{Validation of flood maps}

The results of the comparison between the TUD map with reference maps are presented in Table 2. Considering only flood zones connected with catchments bigger than $500 \mathrm{~km}^{2}, 84 \%$ of the JRC's flood zone is also present in the TUD map (indicator $I_{\text {cor }}$ ). However, the JRC map indicates $246000 \mathrm{~km}^{2}$ at risk of flooding within the domain of the TUD map, which in turn shows almost $330000 \mathrm{~km}^{2}$ within the 100 -year flood extent. The average fit $\left(I_{\text {fit }}\right)$ is $56 \%$, with the lowest values observed in northern Europe, with more overlap observed in central Europe and the Danube basin.

In the second part of Table 2 the TUD map is compared with local reference maps in all available scenarios. A snapshot of the comparison for Trent river basin in central England is presented in Fig. 7. Large variability in the results is observed; most of the time 50-70\% flood zones from the detailed maps are recreated in the TUD maps. The highest value of $I_{\text {cor }}$ (up to $80 \%$ ) was observed in Saxony-Anhalt and some parts of England, and the lowest values were in Switzerland and parts of Saxony (down to $30 \%$ ). $I_{\text {cor }}$ decreases both in Austria and England between 30- and 100year scenarios, but improves again for more extreme floods. $I_{\text {fit }}$ is mostly below $30 \%$, but improves when moving from less extreme to more severe scenarios. All local maps include effects of flood defences; therefore this exact pattern would be expected: flood zones expand rapidly with the increase of the return period of flood, as a declining number of defences can withstand the rising water levels. Hence, variation of the values of $I_{\text {fit }}$ can be mostly explained by the differences in flood protection standards. In England, flood defences are mostly expected to protect against return periods of floods of about 75-200 years (Chatterton et al., 2010). Hence, the protection structures should not influence the size of the 1000year flood zone in England. Indeed, in this scenario and region the highest $I_{\text {cor }}$ and $I_{\text {fit }}$ values were observed at 68 and $53 \%$, respectively. Results were achieved in terms of alignment with the TUD map. The average value of $I_{\mathrm{fit}}$ is two times higher $(53 \%)$ than in the 30-year scenario (24\%). Furthermore, the highest protection level in England is expected in London (Scussolini et al., 2016), which had the lowest $I_{\text {fit }}$ in the 30- and 100-year scenarios.

In other analysed regions, the flood protection standards are mostly higher in terms of return periods than in England: 100-500 years in Germany, 100-1000 years in Austria (highest along the Danube) and 30-200 years in Switzerland (Scussolini et al., 2016; te Linde et al., 2011). For the 100 -year scenario, $I_{\text {fit }}$ is only $24-27 \%$. In Saxony, Dresden district had lower fit than the other two districts, which is consistent with the fact that the city of Dresden has an improved flood protection level of 500 years as opposed to 100 years in other areas. The test measures used also improve visibly in Austria between 100- and 300-year scenarios. On the other hand, the lowest performance of the TUD map in Switzerland can be explained with the characteristics of the flood map, rather than high protection standards. The 300year flood layer could be extracted only for populated areas, which have much better protection than uninhabited areas. The 1000-year flood map is also incomplete, and was compiled for this comparison from flood zones with an unknown, but presumably high, return period.

Finally, both pan-European maps are compared with the local reference maps for the 100-year scenario for catchments bigger than $500 \mathrm{~km}^{2}$ (Table 3). In England the performance of the TUD map was better than the JRC's map, but not in all parts of it. When comparing it with German and Austrian maps, the performance was similar or slightly lower. Summing up all flooded areas, the results show that the TUD map had higher values of both $I_{\text {cor }}$ and $I_{\text {fit }}$. Yet, this results could be explained by some drawbacks of the GIS analysis. In particular, it was problematic to completely filter out from the TUD and local maps the flood zones below the threshold of $500 \mathrm{~km}^{2}$ catchment area. That could have increased the overlap between TUD and local maps to a slightly higher degree than the overlap between the JRC and local maps. Also, in many areas of England better performance can be attributed to several large zones where both river and coastal floods occur, which favours overestimation of flooded area from the rivers. Lastly, English flood zones 


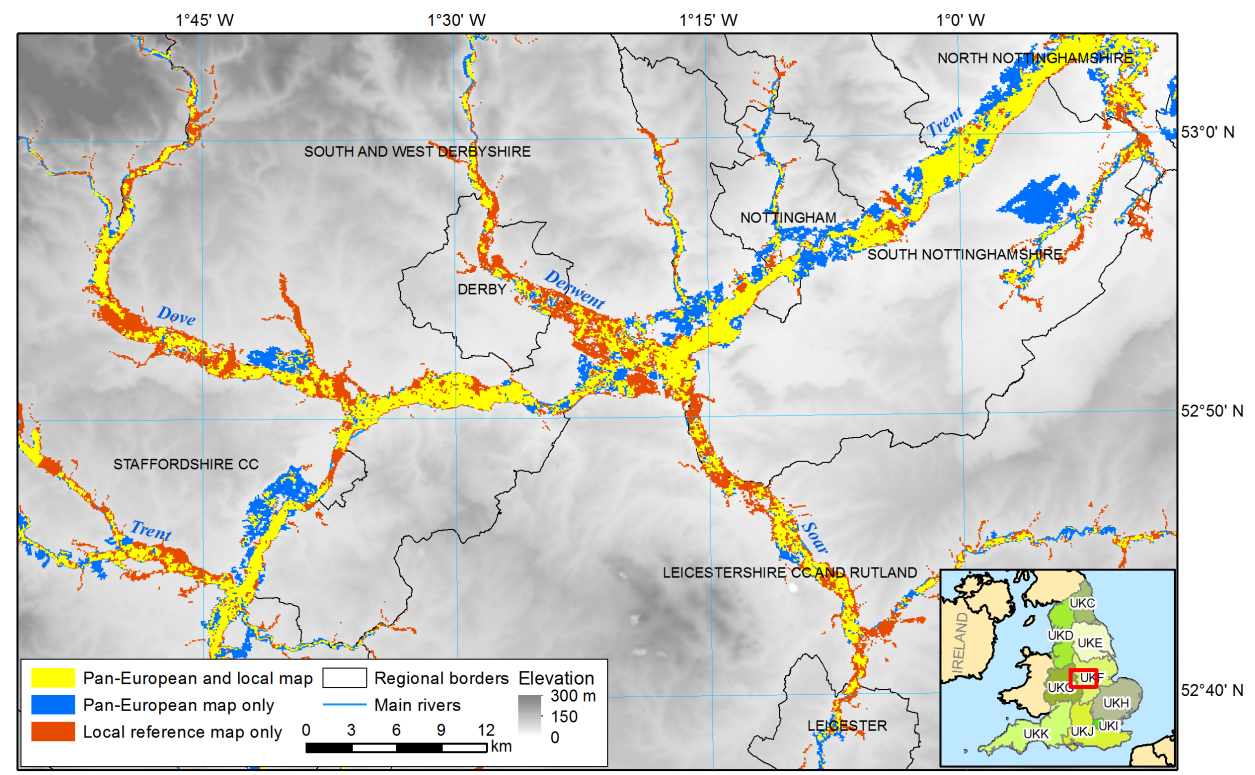

Figure 7. An example of the differences between the pan-European map from this study and the local reference map, in this case for the central part of England for the 100-year flood scenario (Environment Agency, 2016).

Table 2. Comparison of the TUD pan-European flood map with reference flood maps.

\begin{tabular}{|c|c|c|c|c|c|c|c|c|c|}
\hline \multirow{3}{*}{\multicolumn{2}{|c|}{ Region }} & \multicolumn{8}{|c|}{ Flood map test measures by return period } \\
\hline & & \multicolumn{2}{|c|}{30 years } & \multicolumn{2}{|c|}{100 years } & \multicolumn{2}{|c|}{300 years } & \multicolumn{2}{|c|}{1000 years } \\
\hline & & $I_{\text {cor }}(\%)$ & $I_{\text {fit }}(\%)$ & $I_{\text {cor }}(\%)$ & $I_{\text {fit }}(\%)$ & $I_{\text {cor }}(\%)$ & $I_{\text {fit }}(\%)$ & $I_{\text {cor }}(\%)$ & $I_{\text {fit }}(\%)$ \\
\hline \multicolumn{10}{|c|}{ Comparison with the JRC map by subsimulation, catchments $>500 \mathrm{~km}^{2}$} \\
\hline \multirow{8}{*}{\multicolumn{2}{|c|}{$\begin{array}{l}\text { Full domain } \\
\text { Central Europe } \\
\text { British Isles and Iberian peninsula } \\
\text { Southern Europe } \\
\text { Western Europe } \\
\text { Danube basin } \\
\text { North-eastern Europe } \\
\text { Scandinavia }\end{array}$}} & & & 80.2 & 51.1 & & & & \\
\hline & & & & 81.2 & 57.7 & & & & \\
\hline & & & & 76.7 & 43.5 & & & & \\
\hline & & & & 80.1 & 48.2 & & & & \\
\hline & & & & 75.7 & 50.1 & & & & \\
\hline & & & & 86.3 & 54.0 & & & & \\
\hline & & & & 69.1 & 41.7 & & & & \\
\hline & & & & 63.2 & 42.3 & & & & \\
\hline \multicolumn{10}{|c|}{ Comparison with local flood maps by NUTS regions, catchments $>100 \mathrm{~km}^{2}$} \\
\hline UKC-UKK & England & 62.7 & 24.0 & 69.6 & 44.9 & & & 68.5 & 52.8 \\
\hline UKC & North-east & 57.9 & 21.9 & 59.7 & 33.7 & & & 60.1 & 40.0 \\
\hline UKD & North-west & 48.5 & 23.0 & 47.7 & 26.7 & & & 51.8 & 39.3 \\
\hline UKE & Yorkshire and the Humber & 73.1 & 20.5 & 69.5 & 36.6 & & & 68.2 & 48.7 \\
\hline UKF & East Midlands & 62.8 & 17.7 & 73.5 & 46.0 & & & 73.6 & 57.8 \\
\hline UKG & West Midlands & 66.2 & 38.7 & 64.2 & 42.6 & & & 65.7 & 47.0 \\
\hline UKH & East of England & 58.3 & 15.8 & 80.4 & 59.1 & & & 78.1 & 63.2 \\
\hline UKI & London & 68.8 & 13.8 & 64.8 & 17.4 & & & 70.9 & 49.4 \\
\hline UKJ & South-east & 64.7 & 36.4 & 63.1 & 42.7 & & & 60.7 & 48.8 \\
\hline UKK & South-west & 62.6 & 41.4 & 61.2 & 46.1 & & & 58.4 & 47.0 \\
\hline DED & Sachsen (Saxony) & & & 50.3 & 27.4 & & & & \\
\hline DED2 & Dresden & & & 45.3 & 22.5 & & & & \\
\hline DED4 & Chemnitz & & & 33.7 & 24.0 & & & & \\
\hline DED5 & Leipzig & & & 60.8 & 33.8 & & & & \\
\hline DEE & Sachsen-Anhalt (Saxony-Anhalt) & & & 67.9 & 23.6 & & & & \\
\hline AT12 & Niederösterreich (Lower Austria) & 55.0 & 21.9 & 49.5 & 24.3 & 61.8 & 34.4 & & \\
\hline $\mathrm{CH} 021$ & Bern & & & & & 34.9 & 19.1 & 29.2 & 20.7 \\
\hline
\end{tabular}


Table 3. Comparison of the pan-European flood maps with the local reference flood maps. Includes only river with catchment area bigger than $500 \mathrm{~km}^{2}$.

\begin{tabular}{llcc|cc}
\hline Region & & \multicolumn{2}{c}{$I_{\text {cor }}(\%)$} & \multicolumn{2}{c}{$I_{\text {fit }}(\%)$} \\
NUTS & Name & JRC & TUD & JRC & TUD \\
\hline UKC-UKK & England & 50.6 & 77.5 & 38.6 & 43.4 \\
UKC & North-east & 54.3 & 67.4 & 38.6 & 39.9 \\
UKD & North-west & 49.7 & 52.3 & 36.0 & 25.3 \\
UKE & Yorkshire and the Humber & 62.2 & 75.9 & 37.3 & 32.9 \\
UKF & East Midlands & 54.4 & 77.6 & 42.3 & 37.0 \\
UKG & West Midlands & 73.6 & 74.2 & 55.5 & 45.8 \\
UKH & East of England & 40.9 & 87.5 & 35.9 & 63.5 \\
UKI & London & 57.1 & 68.7 & 16.3 & 14.6 \\
UKJ & South-east & 54.2 & 68.0 & 38.8 & 39.4 \\
UKK & South-west & 38.3 & 71.5 & 33.6 & 44.1 \\
DED & Sachsen (Saxony) & 57.3 & 60.9 & 35.1 & 30.0 \\
DED2 & Dresden & 44.9 & 57.0 & 29.3 & 24.9 \\
DED4 & Chemnitz & 49.9 & 49.0 & 30.0 & 30.7 \\
DED5 & Leipzig & 70.3 & 67.3 & 41.1 & 35.4 \\
DEE & Sachsen-Anhalt (Saxony-Anhalt) & 68.5 & 73.4 & 25.2 & 23.3 \\
AT12 & Niederösterreich (Lower Austria) & 54.2 & 59.6 & 23.9 & 26.3 \\
& All regions & 54.1 & 74.0 & 33.2 & 36.1 \\
\hline
\end{tabular}

are twice as large as the remaining ones taken together. Still, the results of fitting both European maps in Saxony-Anhalt and Lower Austria are very similar. Substantial simplification of the methodology of making the European maps did not result in an equal drop in accuracy, but it was largely maintained. The computational time on a regular desktop PC was slightly less than a day per scenario.

\subsection{Present flood hazard in Europe}

River flood hazard maps were prepared and analysed here in two variants: without flood protection and with flood protection as estimated in the FLOPROS database (Scussolini et al., 2016). Full-size images of the maps were included in the supplement. The total area identified within 1000-year flood scenario was almost $389000 \mathrm{~km}^{2}$, which is about six times more than the total for coastal flood hazard (Groenemeijer et al., 2016) if we do not include impact of flood defences. In this section we briefly describe the outcomes of the historical scenario (1971-2000).

The majority of the flood zones in the domain were 10year zones, with only one-sixth belonging to other zones. More than half of the flood hazard was concentrated in only seven countries: Germany, Hungary, France, Romania, Italy, Russia (even though only a small part of this country is included in the domain) and Poland. Splitting the hazard zones by river basin, half of the endangered area is also in only seven of them: Danube (mainly in Austria, Hungary, Serbia and Romania), Neva (Russia), Vistula (Poland), Elbe (mainly Germany), Oder (mostly Poland and Germany), Rhine (mainly Germany) and Po (Italy). Twenty river basins with the highest area within flood zones are listed in Fig. 8.
Taking into account flood defences, the estimated area of the 1000-year zone is revised downwards only slightly, to $376000 \mathrm{~km}^{2}$. A decrease in flood extent is noticeable only in the Netherlands, where the dyke rings provide a high level of protection from both coastal and river floods, and Austria, where flood defences along the Danube are considered to have a high protection standard. On the other end of the scale, the 10-year flood zone is mostly constrained to the Dniester river catchment $\left(6400 \mathrm{~km}^{2}\right)$, while the 30 -year zone is mostly present in the Balkans and former Soviet Union (basins of Danube, Nemunas, Evros and others).

The country with the largest hazard level proportional to its area is Hungary, as $37 \%$ of the country lies within the 1000 -year zone. The Netherlands comes second when flood defences are not considered, with $26 \%$ of the territory in the flood zone. This value, however, drops to $1 \%$ when considering flood protection. Other countries with a high fraction of territory in the flood zone include Serbia (24\%), Croatia $(20 \%)$ and Slovakia $(14 \%)$, all of which are located in the Danube basin. This river system does not have only the biggest basin in the domain and the largest flood extent, but also the highest proportion of flood area compared to total area $(15 \%)$ among large river basins. Increased hazard is also present in the Po river basin $(12 \%)$, Weser $(10 \%)$ and Oder $(9 \%)$. In contrast, Nordic countries have low levels of relative hazard, from $1 \%$ in Norway to $4 \%$ in Finland. Only $3 \%$ of the territory is in hazard zones in Ireland, Portugal, Spain and Switzerland, while in France, the United Kingdom and Austria the figure is $5 \%$, in Poland $8 \%$ and in Germany $10 \%$. 
(a) Without flood protection scenario

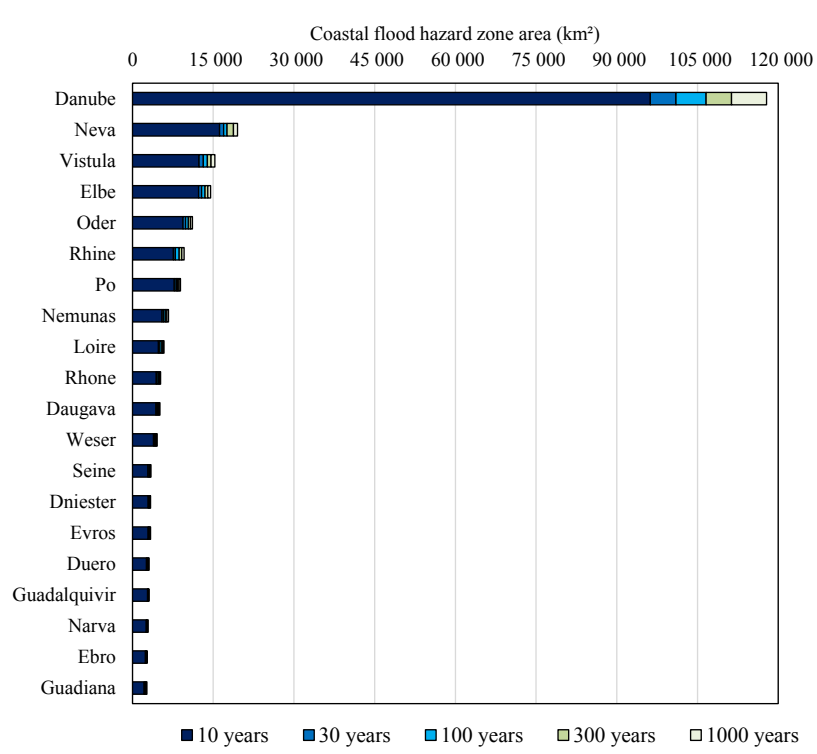

(b) With (estimated) flood protection scenario

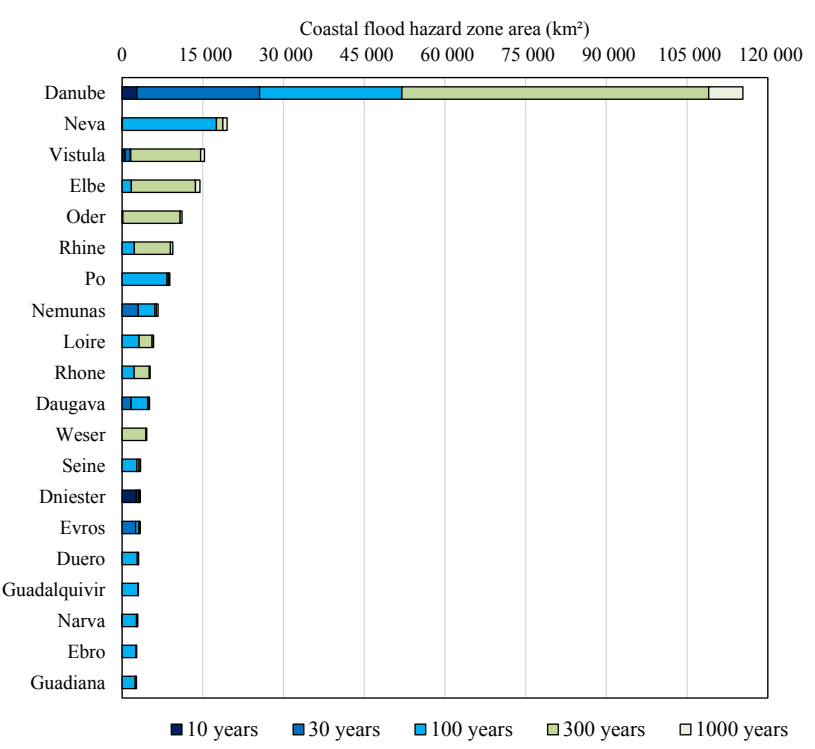

Figure 8. Area of flood hazard zones in 20 river basins with the largest hazard, without and with (estimated) flood protection. The basins listed here are highlighted in the maps in the Supplement.

\subsection{Future flood hazard in Europe}

The overall size of the river flood hazard zones in Europe increased for all four climate change scenarios considered. Yet, without considering flood defences the increases are small. By the mid-century (2021-2050), RCP 4.5 scenario adds $1.7 \%$ to the 1000 -year zone, while RCP 8.5 adds $2.1 \%$ compared to 1971-2000. For 2071-2100, these figures are 4.4 and $2.5 \%$, respectively (Fig. 9). This is largely a result of only a modest (on average) increase in river discharge in Europe. As a whole, this corresponds to 5-8\% depending on the scenario, according to the results from Paprotny and Morales Nápoles (2017). However, the significant implications of changes in discharge becomes apparent when taking into account flood protection standards. The 10-year zone, estimated at $6400 \mathrm{~km}^{2}$ in $1971-2000$, is projected to reach $28000-50000 \mathrm{~km}^{2}$ (4-8 times more), depending on time period and emission scenario. The largest expansion in absolute terms was calculated for the 30-year zone, from $43200 \mathrm{~km}^{2}$ in the end of the 20th century to $130000-183000 \mathrm{~km}^{2}$ (301$423 \%$ increase). The 100 -year zone is expected to be larger by $28-38 \%$ compared to $215000 \mathrm{~km}^{2}$ in the historical scenario. Smaller changes are expected in flood hazards with a lower probability of occurrence: the 300-year zone is actually projected to decrease by $0.7-4.4 \%$, while the 1000 -year zone could add $1.8-5 \%$.

Nevertheless, trends in river flood hazard will be very diversified across Europe. Changes in flood extents presented in Fig. 10 were aggregated to a $50 \times 50 \mathrm{~km}$ grid for the sake of clarity. It includes only one scenario (100-year flood), but the trends shown are also representative for other return periods.

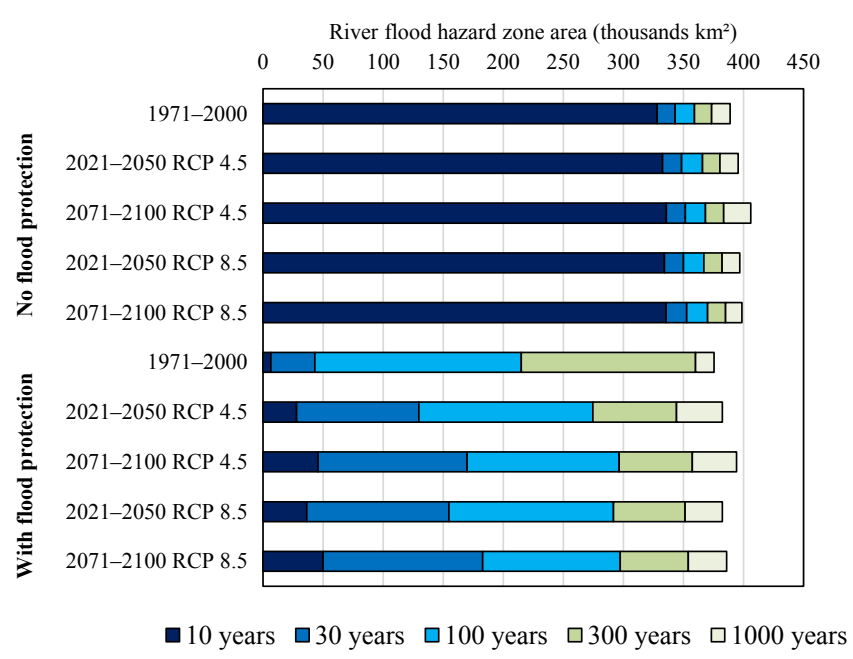

Figure 9. Flood hazards zone area in Europe by scenario, without and with (estimated) flood protection. Predictions based on ECEARTH-COSMO_4.8_clm17 climate model run.

Figure 11 shows the contributions of each country relative to the overall change in flood zone size. With or without flood defences, the largest increases in flood hazard area are projected in central Europe, particularly in Germany, Hungary and Poland. Trends in the Danube basins will be the main source of increase in hazard. The Elbe basin will contribute more than the Rhine, while in Poland flood zones along the Oder are projected to expand more than those along Vistula river. An increase in flood hazard is also projected in France. In the United Kingdom, increases are observed when flood 

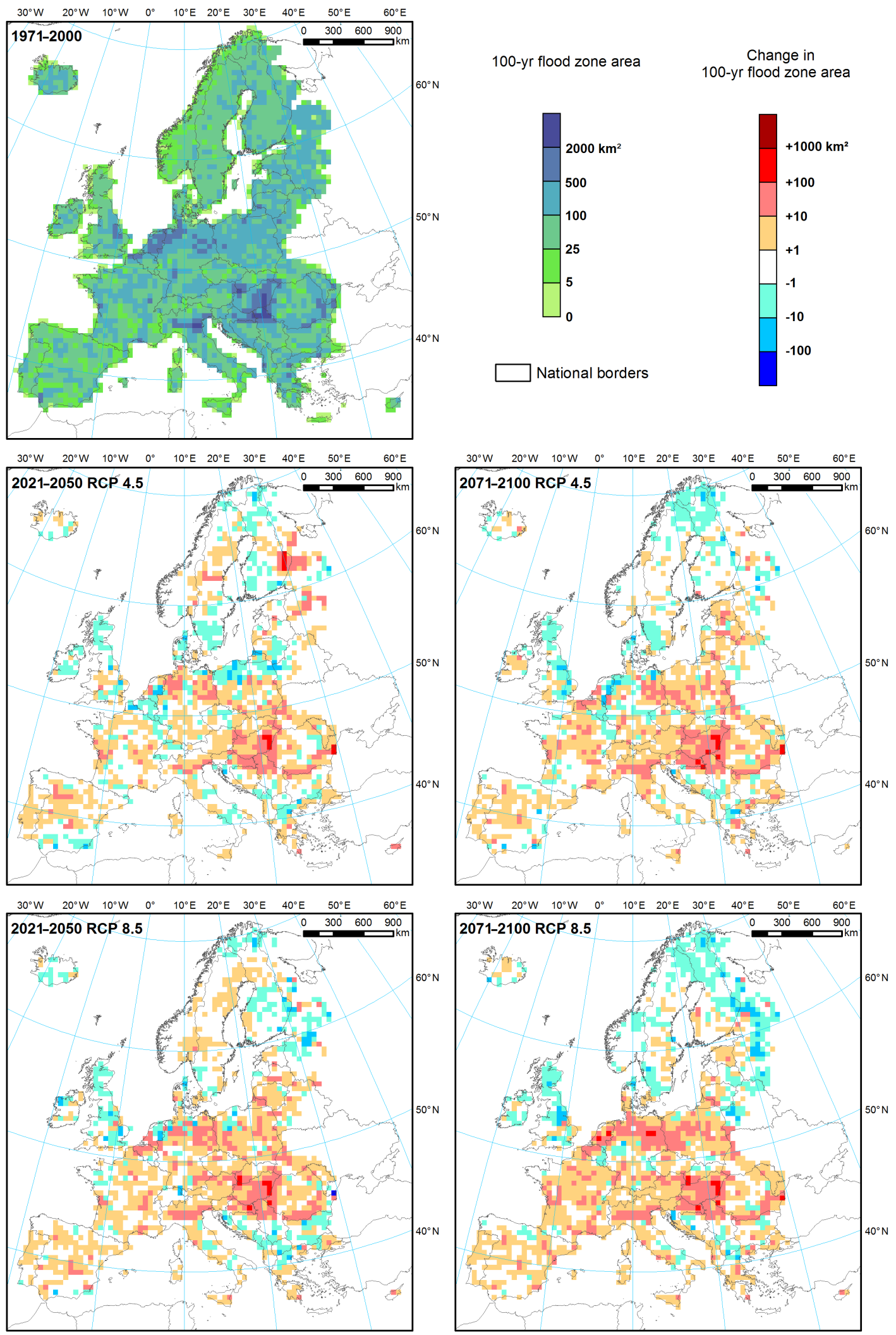

Figure 10. Total area of 100-year river flood hazard zones (no flood protection) aggregated to $50 \times 50 \mathrm{~km}$ grid, and changes under climate scenarios. Predictions based on EC-EARTH-COSMO_4.8_clm17 climate model run. 


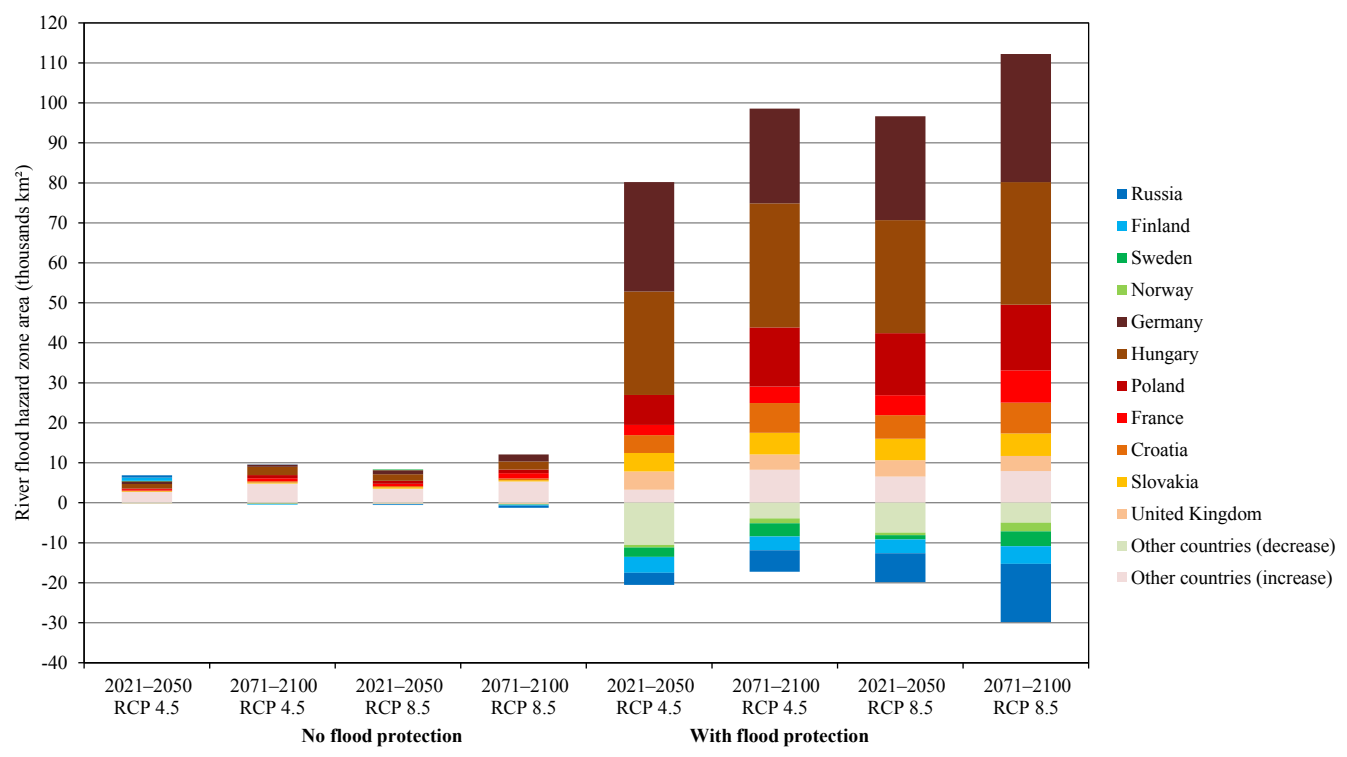

Figure 11. Contributions of selected countries to future changes in 100-year flood zone area in Europe by scenario, without and with (estimated) flood protection. Predictions based on EC-EARTH-COSMO_4.8_clm17 climate model run.

defences are included, but a slight decrease is predicted without taking them into account. Decreases are mostly observed in northern Europe, particularly in Scandinavia, as a large decline of snowfall and, consequently, snowmelt is expected. To a lesser extent, a decrease of flood hazard is projected in many locations around the Mediterranean Sea, which is projected to receive less extreme rainfall in the future.

\section{Discussion}

The results have shown that relatively simpler methods can give similar accuracy to more computationally demanding models for large-scale flood mapping. In this study, three main simplifications were applied: river discharges derived from a statistical model, river flow calculated using a onedimensional steady-state model without channel geometry and flood zones derived in GIS based on water levels from the hydrodynamic model. The similarity in results to the more complex model used by JRC can be traced to the input data sets, which are mostly the same in various flood studies. For example, the SRTM-derived digital elevation models provides neither the river bed geometry nor the dimensions of flood protection structures. The former can only be obtained through local surveys, despite efforts to approximate river width or depth from global data (Yamazaki et al., 2014). Flood defences were incorporated here using nominal protection standards defined as flood return periods (from Scussolini et al., 2016), but this is only a rough approximation. Yet, as indicated, e.g. in Fig. 9, the difference between "without flood defences" and "with flood defences" scenarios is immense. Therefore, both present and future flood hazard and risk estimates need to take this aspect into account. More aspects are related to this issue, such as the influence of flood defences on river flow. Dams retain water from flood waves, while dykes constrain the river to a narrow space between them. Additionally, overtopping is just one of many dyke failure mechanisms (Vrijling, 2001), while other flood control techniques exist such as bypass channels, e.g. the New Danube that protects Vienna (Kryžanowski et al., 2014). All these analyses are currently feasible only at local or at most national scales, e.g. the recent flood risk assessment in the Netherlands (Vergouwe, 2014). At the European or global level, other techniques will have to be used, such as a formal statistical analysis of the differences between high- and low-resolution maps in order to derive indirect factors that determine the flood protection levels at given locations.

More comparison with local maps would also improve calibration of the large-scale models. So far, other studies have left the models uncalibrated, while here a step has been taken by using JRC's - uncalibrated - flood map. Local maps were not readily available for all subsimulations, even though all EU countries do such studies. Intercomparison between the numerous global flood studies could also show which modelling approaches are most efficient. For example, Sampson et al. (2015) achieved better results than Alfieri et al. (2014) despite using a statistical model of river discharges as input. We were unable, however, to obtain data from that study by the time the work described here had concluded.

Limitations of input data and models of river flow are not the only sources of uncertainty. Not all flood events are included in the study. Only rivers with catchments that have an area of at least $100 \mathrm{~km}^{2}$ were included in the calculation. This omits very small rivers where dangerous flash floods can occur, especially in hilly or mountainous terrain (Marchi et 
al., 2010). Flash floods also appear in places where drainage is insufficient, mainly in urban areas (Nirupama and Simonovic, 2007). Moreover, we estimate the extreme river discharge based on two main factors causing flood - rainfall and snowmelt, while floods in northern Europe are also caused by ice and frazil blocking the river flow (Benito et al., 2015). In estuaries, flood hazard is influenced by tides and storm surges, as they might occur at the same time as a river flood (Svensson and Jones, 2004; Petroliagkis et al., 2016). Finally, disastrous floods could be caused by dam breaches (Prettenthaler et al., 2010).

Last, but not least, we should mention the uncertainty related to future climate projections. Only one climate model was used in the Bayesian network model for extreme river discharges. Also, as shown in Figs. 9-11 and the description, the difference between RCP 4.5 and RCP 8.5 scenarios is sometimes very large. The uncertainty is therefore significant and unavoidable as the differences between models and scenarios are considerable, especially concerning precipitation (Rajczak et al., 2013; Kotlarski et al., 2014). Those aspects, however, do not affect the validation results in Sect. 3.1.

\section{Conclusions}

In this study we have investigated the feasibility of creating pan-European flood maps using a simplified modelling approach. A one-dimensional steady-state hydrodynamic model of river flow was utilized to derive flood depths and flood zones were mapped in GIS. It can be concluded that this approach largely fulfilled its aims of reducing complexity while preserving an acceptable level of accuracy. First, the method has a low computational burden - performing a full simulation for Europe takes less than a day on a regular desktop PC, in contrast to months that would have been necessary if using a more advanced model. Second, the comparison with reference flood maps has shown that the method has similar accuracy to the JRC map, which was made by employing 2-D hydraulic models which are significantly more expensive computationally, but in general have shown a tendency to overestimate the size of the flood zones. Additionally, the river discharge data used in this study originated from a statistical model instead of a rainfall-run-off model commonly used in other modelling approaches.

The results are also an indication that the resolution and completeness of input data have high importance compared to the choice of modelling approach. For instance, the flood protection standards as modelled in this research influence the size of the flood zones profoundly, both for the present and future scenarios. The assumption of perfect reliability of flood protection standards could be relaxed and further investigated in future research. Yet, the reliability of global flood defence data is rather low and considerable improvements need to be made. This aspect is where large gains in accuracy of continental or global-scale maps could be made.
Then, more detailed digital elevation models are needed as well as data on river beds. Uncertainty of river discharge return periods and their future development should be further reduced by more research into statistical models.

Data availability. This work relied entirely on public data as input, which are available from the providers cited in the paper. Results of the work can be downloaded from an online repository at https://doi.org/10.4121/uuid:968098ce-afe14b21-a509-dedaf9bf4bd5 (Paprotny and Morales Nápoles, 2016).

\section{The Supplement related to this article is available online at https://doi.org/10.5194/nhess-17-1267-2017- supplement.}

Competing interests. The authors declare that they have no conflict of interest.

Acknowledgements. This work was supported by European Union's Seventh Framework Programme under "Risk analysis of infrastructure networks in response to extreme weather" (RAIN) project, grant no. 608166, and the European Union's Horizon 2020 research and innovation programme under the Bridging the Gap for Innovations in Disaster resilience (BRIGAID) project, grant no. 700699. This paper benefited from valuable comments by Antonia G. Sebastian and two anonymous reviewers.

Edited by: Paolo Tarolli

Reviewed by: two anonymous referees

\section{References}

Alfieri, L., Salamon, P., Bianchi, A., Neal, J., Bates, P., and Feyen, L.: Advances in pan-European flood hazard mapping, Hydrol. Process., 28, 4067-4077, https://doi.org/10.1002/hyp.9947, 2014.

Alfieri, L., Burek, P., Feyen, L., and Forzieri, G.: Global warming increases the frequency of river floods in Europe, Hydrol. Earth Syst. Sci., 19, 2247-2260, https://doi.org/10.5194/hess-19-22472015, 2015a.

Alfieri, L., Feyen, L., Dottori, F., and Bianchi, A.: Ensemble flood risk assessment in Europe under high end climate scenarios, Global Environ. Chang., 35, 199-210, https://doi.org/10.1016/j.gloenvcha.2015.09.004, 2015b.

Amt der NÖ Landesregierung: Download von Geodaten und Karten, available at: http://www.noel.gv.at/Land-Zukunft/ Karten-Geoinformation/Karten-Geodaten-Angebot/ DownloadGeodatenKarten.html (last access: 28 August 2016), 2016.

Apel, H., Aronica, G. T., Kreibich, H., and Thieken, A. H.: Flood risk analyses - how detailed do we need to be?, Nat. Hazards, 49, 79-98, https://doi.org/10.1007/s11069-008-9277-8, 2009. 
Bates, P. D. and De Roo, A. P. J.: A simple raster-based model for flood inundation simulation, J. Hydrol., 236, 54-77, https://doi.org/10.1016/S0022-1694(00)00278-X, 2000.

Benito, G., Brázdil, R., Herget, J., and Machado, M. J.: Quantitative historical hydrology in Europe, Hydrol. Earth Syst. Sci., 19, 3517-3539, https://doi.org/10.5194/hess-19-3517-2015, 2015.

Chatterton, J., Viavattene, C., Morris, J., Penning-Rowsell, E., and Tapsell, S.: The costs of the summer 2007 floods in England, Environment Agency, Bristol, United Kingdom, available at: https://www.gov.uk/government/uploads/system/ uploads/attachment_data/file/291190/scho1109brja-e-e.pdf (last access: 11 October 2016), 2010.

De Jager, A. L. and Vogt, J. V.: Development and demonstration of a structured hydrological feature coding system for Europe, Hydrolog. Sci. J., 55, 661-675, https://doi.org/10.1080/02626667.2010.490786, 2010.

Deltares: SOBEK Hydrodynamics, Rainfall Runoff and Real Time Control User Manual, available at: http://content.oss. deltares.nl/delft3d/manuals/SOBEK_User_Manual.pdf, last access: 5 September 2016.

DHI GRAS: EU-DEM Statistical Validation Report, European Environment Agency, Copenhagen, 2014.

Dottori, F., Salamon, P., Bianchi, A., Alfieri, L., Hirpa, F. A., and Feyen, L.: Development and evaluation of a framework for global flood hazard mapping, Adv. Water Resour., 94, 87-102, https://doi.org/10.1016/j.advwatres.2016.05.002, 2016.

Environment Agency: Risk of Flooding from Rivers and Sea, available at: https://data.gov.uk/dataset/ risk-of-flooding-from-rivers-and-sea1, last access: $17 \mathrm{Au}-$ gust 2016.

European Union: Directive 2007/60/EC of the European Parliament and of the Council of 23 October 2007 on the assessment and management of flood risks, OJ L 288, 6.11.2007, 27-34, 2007.

Eurostat: Regions in the European Union - Nomenclature of territorial units for statistics - NUTS 2013/EU-28, Publications Office of the European Union, Luxembourg, https://doi.org/10.2785/53780, 2015.

Feyen, L., Dankers, R., Bódis, K., Salamon, P., and Barredo, J. I.: Fluvial flood risk in Europe in present and future climates, Climatic Change, 112, 47-62, https://doi.org/10.1007/s10584-0110339-7, 2012.

Groenemeijer, P., Vajda, A., Lehtonen, I., Kämäräinen, M., Venäläinen, A., Gregow, H., Becker, N., Nissen, K., Ulbrich, U., Paprotny, D., Morales Nápoles, O., and Púčik, T.: Present and future probability of meteorological and hydrological hazards in Europe, D2.5 report, RAIN project, available at: http://rain-project.eu/wp-content/uploads/2016/09/D2. 5_REPORT_final.pdf, last access: 14 September 2016.

Hirabayashi, Y., Mahendran, R., Koirala, S., Konoshima, L., Yamazaki, D., Watanabe, S., Kim, H., and Kanae, S.: Global flood risk under climate change, Nat. Clim. Change, 3, 816-821, https://doi.org/10.1038/nclimate1911, 2013.

Joint Research Centre: Pan European Flood Hazard Map for a 100 year return period event, available at: http://drdsi.jrc.ec.europa.eu/dataset/ pan-european-flood-hazard-map-for-a-100-year-return-period-event Petroliagkis, T. I., Voukouvalas, E., Disperati, J., and Bil(last access: 1 September 2016), 2014.

Jonkman, S. N.: Advanced flood risk analysis required, Nat. Clim. Change, 3, 1004-1004, 2013.
Kanton Bern: Geoportal des Kantons Bern, available at: http://www. apps.be.ch/geo/, last access: 20 October 2016.

Kotlarski, S., Keuler, K., Christensen, O. B., Colette, A., Déqué, M., Gobiet, A., Goergen, K., Jacob, D., Lüthi, D., van Meijgaard, E., Nikulin, G., Schär, C., Teichmann, C., Vautard, R., Warrach-Sagi, K., and Wulfmeyer, V.: Regional climate modeling on European scales: a joint standard evaluation of the EUROCORDEX RCM ensemble, Geosci. Model Dev., 7, 1297-1333, https://doi.org/10.5194/gmd-7-1297-2014, 2014.

Kryžanowski, A., Brilly, M., Rusjan, S., and Schnabl, S.: Review Article: Structural flood-protection measures referring to several European case studies, Nat. Hazards Earth Syst. Sci., 14, 135142, https://doi.org/10.5194/nhess-14-135-2014, 2014.

Landesbetrieb für Hochwasserschutz und Wasserwirtschaft Sachsen-Anhalt: Hochwassergefahrenkarten - Geodaten der Überschwemmungsflächen herunterladen, available at: http://www.geocms.com/webmap-lsa/de/ hochwassergefahrenkarte-hq100-download.html, last access: 25 October 2016.

Marchi, L., Borga, M., Preciso, E., and Gaume, E.: Characterisation of selected extreme flash floods in Europe and implications for flood risk management, J. Hydrol., 394, 118-133, https://doi.org/10.1016/j.jhydrol.2010.07.017, 2010.

Mokrech, M., Kebede, A. S., Nicholls, R. J., Wimmer, F., and Feyen, L.: An integrated approach for assessing flood impacts due to future climate and socio-economic conditions and the scope of adaptation in Europe, Climatic Change, 128, 245-260, https://doi.org/10.1007/s10584-014-1298-6, 2015.

Moss, R. H., Edmonds, J. A., Hibbard K. A., Manning M. R., Rose, S. K., and Wilbanks, T. J.: The next generation of scenarios for climate change research and assessment, Nature, 463, 747-756, https://doi.org/10.1038/nature08823, 2010.

Nirupama, N. and Simonovic, S. P.: Increase of flood risk due to urbanisation: a Canadian example, Nat. Hazards, 40, 25-41, https://doi.org/10.1007/s11069-006-0003-0, 2007.

Pappenberger, F., Dutra, E., Wetterhall, F., and Cloke, H. L.: Deriving global flood hazard maps of fluvial floods through a physical model cascade, Hydrol. Earth Syst. Sci., 16, 4143-4156, https://doi.org/10.5194/hess-16-4143-2012, 2012.

Paprotny, D. and Morales Nápoles, O.: A Bayesian Network for extreme river discharges in Europe, in: Safety and Reliability of Complex Engineered Systems, edietd by: Podofillini, L., Sudret, B., Stojadinović, B., Zio, E., and Kröger, W., CRC Press/Balkema, Leiden, The Netherlands, 4303-4311, 2015.

Paprotny, D. and Morales Nápoles, O.: Pan-European data sets of river flood probability of occurrence under present and future climate, TU Delft, dataset, https://doi.org/10.4121/uuid:968098ceafe1-4b21-a509-dedaf9bf4bd5, 2016.

Paprotny, D. and Morales-Nápoles, O.: Estimating extreme river discharges in Europe through a Bayesian network, Hydrol. Earth Syst. Sci., 21, 2615-2636, https://doi.org/10.5194/hess-21-26152017, 2017.

Pearl, J.: Probabilistic Reasoning in Intelligent Systems: Networks of Plausible Inference, Morgan Kaufmann, San Mateo, California, USA, 1988.

dot, J.: Joint Probabilities of Storm Surge, Significant Wave Height and River Discharge Components of Coastal 
Flooding Events, JRC Technical Report EUR 27824 EN, https://doi.org/10.2788/677778, 2016.

Prettenthaler, F., Amrusch, P., and Habsburg-Lothringen, C.: Estimation of an absolute flood damage curve based on an Austrian case study under a dam breach scenario, Nat. Hazards Earth Syst. Sci., 10, 881-894, https://doi.org/10.5194/nhess-10-8812010, 2010.

Rajczak, J., Pall, P., and Schär, C.: Projections of extreme precipitation events in regional climate simulations for Europe and the Alpine Region, J. Geophys. Res.-Atmos., 118, 3610-3626, https://doi.org/10.1002/jgrd.50297, 2013.

Rockel, B., Will, A., and Hense, A.: Special issue regional climate modelling with COSMO-CLM (CCLM), Meteorol. Z., 17, 347348, 2008 .

Rojas, R., Feyen, L., Dosio, A., and Bavera, D.: Improving pan-European hydrological simulation of extreme events through statistical bias correction of RCM-driven climate simulations, Hydrol. Earth Syst. Sci., 15, 2599-2620, https://doi.org/10.5194/hess-15-2599-2011, 2011.

Rojas, R., Feyen, L., Bianchi, A., and Dosio, A.: Assessment of future flood hazard in Europe using a large ensemble of biascorrected regional climate simulations, J. Geophys. Res., 117, D17109, https://doi.org/10.1029/2012JD017461, 2012.

Rojas, R., Feyen, L., and Watkiss, P.: Climate change and river floods in the European Union: Socioeconomic consequences and the costs and benefits of adaptation, Global Environ. Chang., 23, 1737-1751, https://doi.org/10.1016/j.gloenvcha.2013.08.006, 2013.

Sächsisches Landesamt für Umwelt, Landwirtschaft und Geologie: Geodatendownload des Fachbereichs Wasser, available at: http://www.umwelt.sachsen.de/umwelt/wasser/10002. htm?data=ueg, last access: 29 August 2016.

Sampson, C. C., Smith, A. M., Bates, P. D., Neal, J. C., Alfieri, L., and Freer, J. E.: A high-resolution global flood hazard model, Water Resour. Res., 51, 7358-7381, https://doi.org/10.1002/2015WR016954, 2015.

Scussolini, P., Aerts, J. C. J. H., Jongman, B., Bouwer, L. M., Winsemius, H. C., de Moel, H., and Ward, P. J.: FLOPROS: an evolving global database of flood protection standards, Nat. Hazards Earth Syst. Sci., 16, 1049-1061, https://doi.org/10.5194/nhess16-1049-2016, 2016.

Smith, A., Sampson, C., and Bates, P.: Regional flood frequency analysis at the global scale, Water Resour. Res., 51, 539-553, https://doi.org/10.1002/2014WR015814, 2015.

Svensson, C. and Jones, D. A.: Dependence between sea surge, river flow and precipitation in south and west Britain, Hydrol. Earth Syst. Sci., 8, 973-992, https://doi.org/10.5194/hess-8-973-2004, 2004
Te Linde, A. H., Bubeck, P., Dekkers, J. E. C., de Moel, H., and Aerts, J. C. J. H.: Future flood risk estimates along the river Rhine, Nat. Hazards Earth Syst. Sci., 11, 459-473, https://doi.org/10.5194/nhess-11-459-2011, 2011.

Thielen, J., Bartholmes, J., Ramos, M.-H., and de Roo, A.: The European Flood Alert System - Part 1: Concept and development, Hydrol. Earth Syst. Sci., 13, 125-140, https://doi.org/10.5194/hess-13-125-2009, 2009.

Van der Knijff, J. M., Younis, J., and de Roo, A. P. J.: LISFLOOD: A GIS-based distributed model for river basin scale water balance and flood simulation, Int. J. Geogr. Inf. Sci., 24, 189-212, https://doi.org/10.1080/13658810802549154, 2010.

Vergouve, R.: The National Flood Risk Analysis for the Netherlands, Rijkswaterstaat, available at: http://www.helpdeskwater. nl/publish/pages/33875/vnk-rapport-eng-lr.pdf (last access: 20 September 2016), 2014.

Vogt, J. V., Soille, P., de Jager, A., Rimaviciute, E., Mehl, W., Foisneau, S., and Bamps, C.: A pan-European River and Catchment Database, Report EUR 22920 EN, European Commission-Joint Research Centre, Luxembourg, 120 pp., 2007.

Vrijling, J. K.: Probabilistic design of water defense systems in The Netherlands, Reliab. Eng. Syst. Safe., 74, 337-344, 2001.

Ward, P. J., Jongman, B., Sperna Weiland, F., Bouwman, A., and van Beek, R.: Assessing flood risk at the global scale: model setup, results, and sensitivity, Environ. Res. Lett., 8, 044019, https://doi.org/10.1088/1748-9326/8/4/044019, 2013.

Ward, P. J., Jongman, B., Salamon, P., Simpson, A., Bates, P., and Winsemius, H. C.: Usefulness and limitations of global flood risk models, Nat. Clim. Change, 5, 712-715, https://doi.org/10.1038/nclimate2742, 2015.

Winsemius, H. C., Van Beek, L. P. H., Jongman, B., Ward, P. J., and Bouwman, A.: A framework for global river flood risk assessments, Hydrol. Earth Syst. Sci., 17, 1871-1892, https://doi.org/10.5194/hess-17-1871-2013, 2013.

Winsemius, H. C., Aerts, J. C. H. C., Van Beek, L. P. H., Bierkens, M. F. P., Bouwman, A., and Ward, P. J.: Global drivers of future river flood risk, Nat. Clim. Change, 6, 381-385, https://doi.org/10.1038/nclimate2893, 2015.

Yamazaki, D., O’Loughlin, F., Trigg, M. A., Miller, Z. F., Pavelsky, T. M., and Bates, P. D.: Development of the global width database for large rivers, Water Resour. Res., 50, 3467-3480, https://doi.org/10.1002/2013WR014664, 2014. 